International Journal of Agriculture, Environment and Bioresearch

Vol. 06, No. 06; 2021

ISSN: $2456-8643$

\title{
INFLUENCE OF ORGANO-MINERAL FERTILIZATION RATE ON AGRONOMIC PERFORMANCE OF SANIO MILLET (Pennisetum Glaucum (L.) R. Br.) IN LOWER CASAMANCE (SOUTHERN SENEGAL)
}

\author{
Ismaila $\mathrm{COLY}^{1 *}$; Abdoulaye BADIANE ${ }^{2}$; Yaye Nguenar NDIAYE ${ }^{1}$; Dieynaba BA ${ }^{1}$ and Arfang O. K. \\ GOUDIABY ${ }^{1}$ \\ ${ }^{1}$ Department of Agroforestry, Agroforestry and Ecology Laboratory, Assane SECK University of Ziguinchor, \\ Senegal \\ ${ }^{2}$ Djibélor Agricultural Research Center, Cap Skiring road, Ziguinchor-Senegal
}

https://doi.org/10.35410/IJAEB.2021.5693

\begin{abstract}
The objective of this study is to contribute to the promotion of a sustainable production of Sanio millet in Lower Casamance. This was done by defining the best combination of organic and mineral fertilization levels for optimal and environmentally friendly growth and production of Sanio millet. The system used is a randomized complete block design with four replications or blocks. The studied factor is the organic-mineral fertilization resulting from the combination of the sub-factors compost with three application rates $(0 t$. ha- $1 ; 5 \mathrm{t} / \mathrm{ha} ; 7.5 \mathrm{t}$. ha-1) and the mineralnitrogen fertilization with also three application rates $(0 \%, 50 \%$ and $100 \%$ of the recommended mineral fertilization). The results showed that the interaction between compost and mineral fertilizer was significant on all the parameters studied except for the number of ears. ha- 1 and grain yield. Overall, treatment T8 $(7.5$ t. ha-1 of compost $+100 \%$ recommended mineral fertilization) gave the best results for height $(186.29 \mathrm{~cm})$, crown diameter $(14.08 \mathrm{~mm})$, number of leaves (39 leaves/plant), straw biomass (7.288 t. ha-1), spike biomass (1.219 t. ha-1) and grain yield (0.7781 t. ha-1) On the other hand, treatment T5 (5 t. ha-1 of compost $+100 \%$ recommended mineral fertilization) gave the best result for the number of tillers with 14 tillers $/ \mathrm{m}^{2}$. Compost alone (T3 and T6) improved thousand kernel weight with $5.98 \mathrm{~g}$ for T3 and $6.22 \mathrm{~g}$ for T6. In the context of sustainable management of soil fertility and improvement of millet production in Lower Casamance, the combination of $7.5 \mathrm{t}$. ha-1 of compost and 100\% of the recommended dose of mineral fertilizer would be a practice to be experimented in a farming environment.
\end{abstract}

Keywords: Compost, Mineral Fertilization, Sanio Millet, Agronomic Performance, Lower Casamance.

\section{INTRODUCTION}

The agricultural sector faces the enormous challenge of feeding a growing global population in the midst of climate change [1]. Land degradation in sub-Saharan Africa remains a major concern due to its adverse impacts on agricultural production, food security, and the environment [2]. In Senegal, soil degradation is manifested either by an imbalance of nutrients such as nitrogen and phosphorus, or by a disaggregation of elemental soil assemblages [3] ; [4].

Millet is one of the most widely grown cereals in the semi-arid zones of Africa and India. It is grown on 11.5 million hectares in Africa and 1.7 million hectares in India [5]. In Senegal, it 
represents the most important cereal in terms of production [1] ; [6]. In 2015, its production was 749,874 tons and accounted for about $31 \%$ of national cereal production [7]. Two types of millet are grown in Senegal: the early millet known as Souna and the late millet known as Sanio. Late millet (Sanio) is mainly grown in the most humid regions of Senegal, namely Casamance and Eastern Senegal. Despite, the importance of this crop, yields remain very low $(0.75$ t. ha-1) in farming areas [8] ; [7]. In Casamance, the low production capacity of soils and some traditional millet varieties is limited by poor access to inputs, poor mastery of amendment production technologies by stakeholders.

As a result, the restoration of soil fertility through the use of compost and mineral fertilizer appears to be an imperative. This would increase the structural stability of the soil, reduce the risk of erosion, improve the quality of production and increase agricultural yields.

With this in mind, the general objective of our study is to contribute to the promotion of sustainable production of Sanio millet in Casamance.

Specifically, the aim is to determine the best combination of organo-mineral fertilization levels on the growth and production of Sanio millet in Lower Casamance.

\section{MATERIALS AND METHODS}

\subsection{Experimental site}

The study site was located at the Centre de Recherches Agricoles (CRA) de Djibélor (Figure 1) located at $12^{\circ} 55^{\prime} 90^{\prime \prime}$ latitude North and 16 $30^{\prime} 47^{\prime \prime}$ longitude West in the commune of Niaguis, Ziguinchor region (Senegal). The trial was conducted during the 2020 winter season.

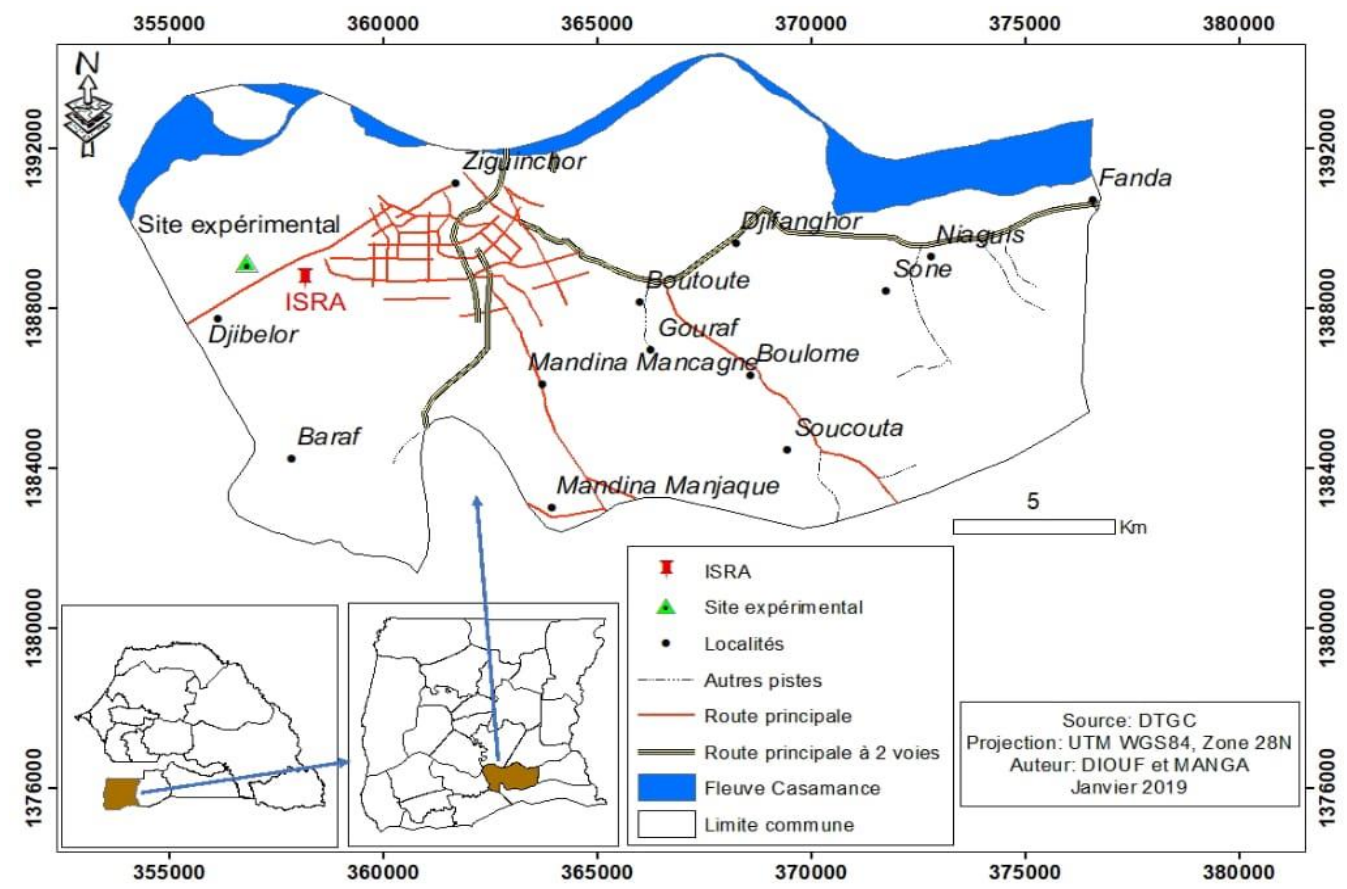

Figure 1: Location of the experimental site. Source: [9] 
The climate is of the coastal South Sudanese type [10] characterized by two seasons. The average annual rainfall over the 1991-2020 series is $1386 \mathrm{~mm}$ (Figure 2). The wettest year in the observed series (2020), recorded $1986 \mathrm{~mm}$ of rainfall, while the two most deficient years were $2002(811.7 \mathrm{~mm})$ and $2007(919.7 \mathrm{~mm})$. The site is located in the continental shelf lands, occupied by dwellings and natural woodlands, with a leached tropical ferruginous soil type.

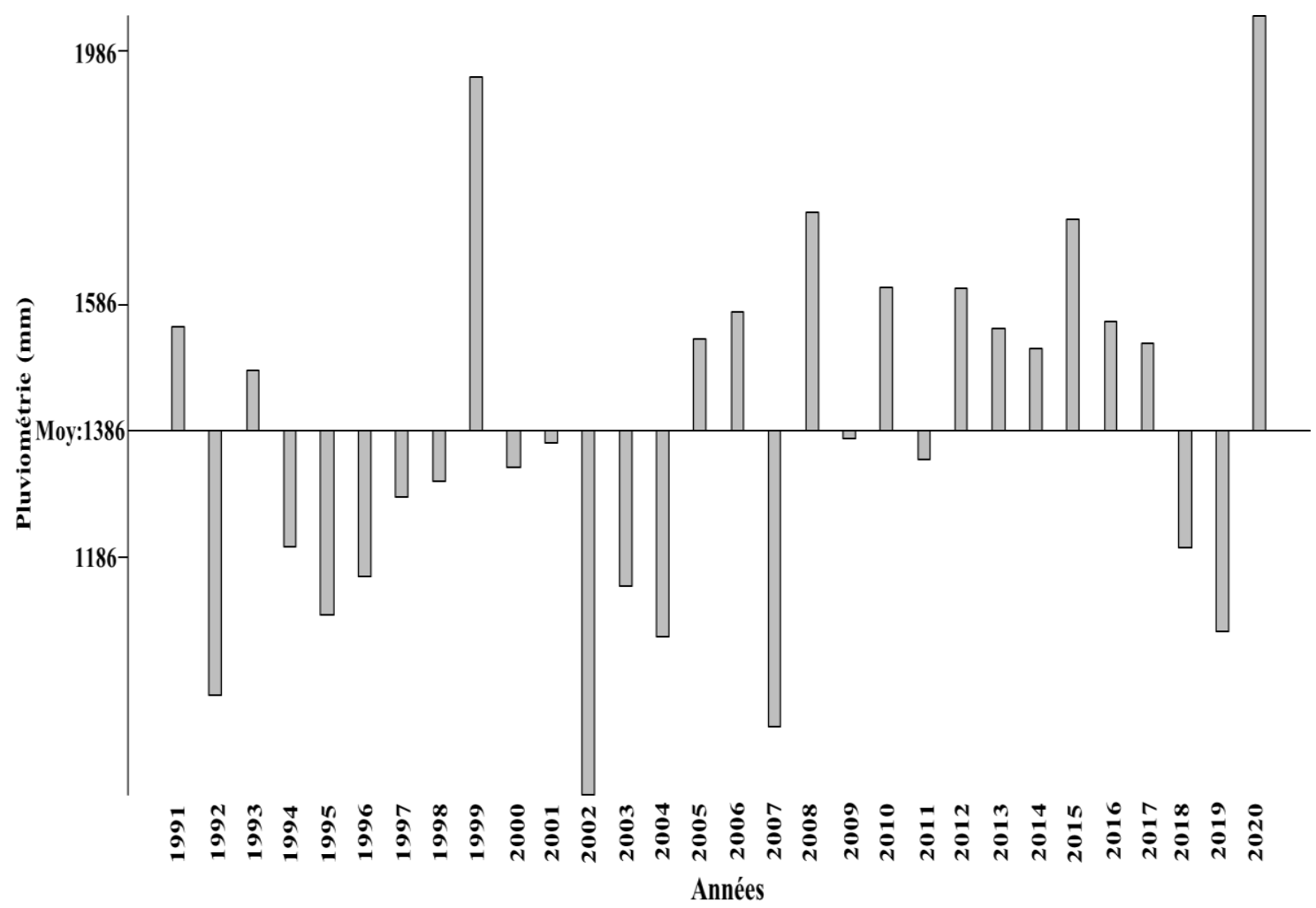

Figure 2: Inter-annual variation in rainfall from 1991 to 2020 in Lower Casamance recorded at the Ziguinchor regional weather station

\subsection{Plant material}

The plant material used is a Sanio millet cultivar grown in Casamance. It has a height of 3 to 3.5 $\mathrm{m}$ and a cropping cycle of 130 to 150 days with aristate ears. It is photoperiodic and only flowers if the day length is sufficiently short [11].

\subsection{The experimental set-up}

The experimental design is a randomized complete block design with 04 replications. Each block is composed of 9 elementary plots corresponding to the 9 treatments. The elementary plots are made up of 6 crop lines with 18 plants per line following a planting geometry of $0.9 \mathrm{~m} \times 0.9 \mathrm{~m} \times 3$ plants/pod, i.e. 37,038 plants. ha-1. The studied factor is the organo-mineral fertilization with two sub-factors (Compost and Nitrogenous Mineral Fertilization). The first sub-factor (compost) consists of three levels of application rates $(0 \mathrm{t}$. ha- $1 ; 5 \mathrm{t}$. ha- $1 ; 7.5 \mathrm{t}$. ha-1). The second (mineral nitrogen fertilization) consists of three levels corresponding to 3 doses of mineral fertilization 
( $0 \%$ of the FMR dose; $50 \%$ of the FMR dose; $100 \%$ of the FMR dose). The experimental unit and the useful square have respective areas of $20.25 \mathrm{~m}^{2}\left(4.5 \mathrm{~m}^{*} 4.5 \mathrm{~m}\right)$ and $16 \mathrm{~m}^{2}\left(4 \mathrm{~m}^{*} 4 \mathrm{~m}\right)$.

NB: RMF = Recommended Mineral Fertilization of Nitrogen (Urea)

\subsection{Conduct of the trial}

The experiment was carried out on a relatively homogeneous flat ground. A ploughing followed by a levelling was carried out a few days before sowing. Sowing was done by hand with 10 millet seeds per plot. An agricultural technique of localization of the contributions at the level of the plant by basins or half-moons was carried out. NPK fertilizer (15-10-10) was used as a background fertilizer with $150 \mathrm{~kg}$. ha-1 applied during sowing. Compost was applied at $31 \mathrm{JAS}$ with a quantity of $445.5 \mathrm{~g}$ per bin for the $5 \mathrm{t}$. ha- 1 dose and $668.25 \mathrm{~g}$ per bin for the $7.5 \mathrm{t}$. ha- 1 dose. Urea was applied in two fractions: the first of $50 \mathrm{~kg}$. ha-1 at the beginning of tillering (31 JAS) and the second of $50 \mathrm{~kg}$. ha- 1 at panicle initiation (65 JAS). The three-plant-per-bunch weeding was carried out on 24 days of the year. Two weedings were carried out respectively at 18 and 48th DAS.

\subsection{Measured parameters}

Measurements were made to monitor morphological parameters (height, crown diameter, number of leaves and number of tillers at 43rd, 57th, 72nd, 87th, 102nd and 117th day after sowing) and production parameters (straw biomass, spike biomass, number of spikes, grain yield and thousand grain weight at harvest) of millet in the experimental plots.

\subsection{Statistical treatments}

The data collected were entered into the Excel spreadsheet version 2016. The latter was used to develop the tables and graphs. XLSTAT 2014 software was used to perform ANOVA and Principal Component Analysis (PCA) and also to compare the means using the Student-Newman and Keuls test of comparison of means at the $5 \%$ significance level.

\section{RESULTS}

\subsection{Effect of treatments on collar diameter and height of millet plants}

The analysis of variance showed that there was a very highly significant difference $(\mathrm{P}<0.0001)$ in the collar diameter of millet plants between the different treatments (Figure 3a). The highest values of collar diameter $(14.08 \mathrm{~mm}$ and $13.46 \mathrm{~mm})$ were obtained with treatments $\mathrm{T} 8\left(7.5 \mathrm{t} . \mathrm{ha}^{-1}\right.$ compost $+100 \%$ of FMR dose) and T7 (7.5 t. ha ${ }^{-1}$ compost $+50 \%$ of FMR dose), respectively.

Regarding the average plant height, the analysis of variance showed that it presented a very highly significant difference $(\mathrm{P}<0.0001)$ between treatments. Treatment $\mathrm{T} 8\left(7.5 \mathrm{t}\right.$. ha $\mathrm{ha}^{-1}$ of compost $+100 \%$ of FMR dose) gave the best result with an average height of $186.29 \mathrm{~cm}$ followed by treatment T4 ( $5 \mathrm{t}$. ha ${ }^{-1}$ of compost $+100 \%$ of FMR dose) with an average height of $176.62 \mathrm{~cm}$ (Figure $3 \mathrm{~b})$. The lowest average plant height was recorded with treatment T0 (0 t. ha ${ }^{-1}$ of compost $+0 \%$ of FMR dose $)(135.18 \mathrm{~cm})$. 

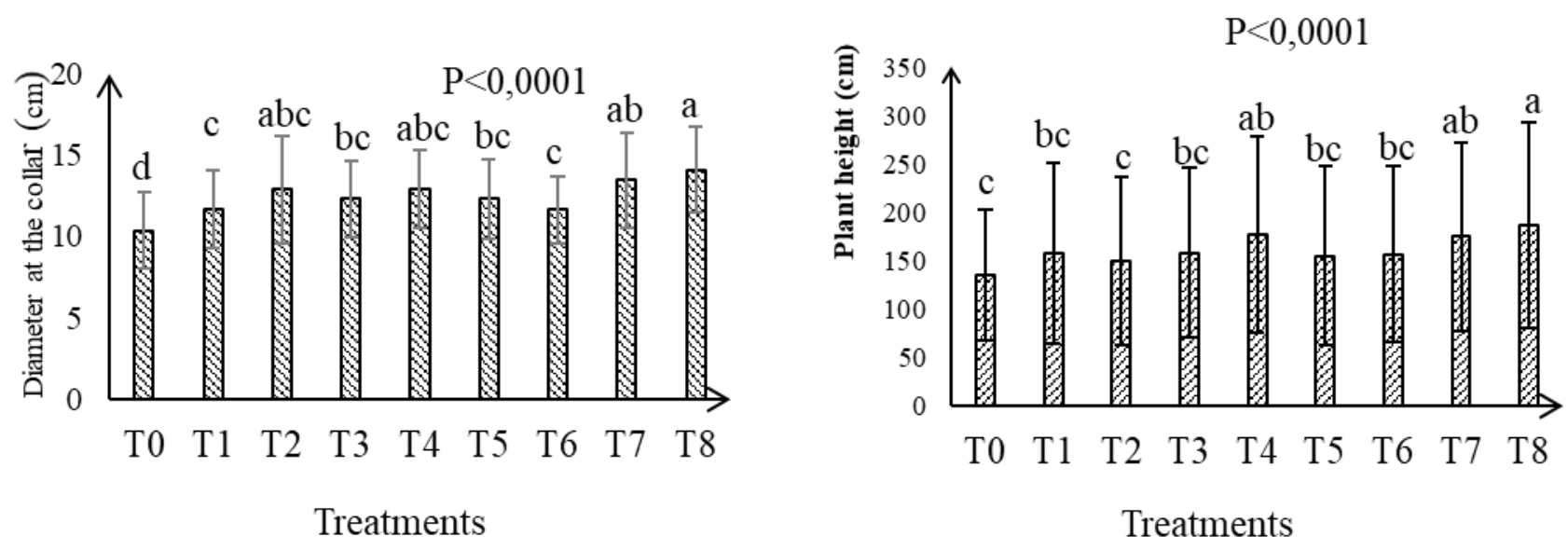

Figure 3: Effect of treatments on collar diameter (a) and height (b) of millet plants.

\subsection{Effect of treatments on leaf and tillers production of sanio millet}

Figure $4 \mathrm{a}$ showed that treatments influenced leaf production of millet plants very highly significantly $(\mathrm{P}<0.0001)$. Treatments T8 $\left(7.5 \mathrm{t}^{\text {. ha }}{ }^{-1}\right.$ compost $+100 \%$ of FMR dose $), \mathrm{T} 2\left(0 \mathrm{t} . \mathrm{ha}^{-1}\right.$ compost $+100 \%$ of FMR dose) and T7 (7.5 t. ha-1 compost $+50 \%$ of FMR dose) gave the best results with 39; 37 and 34 leaves/plant of millet respectively. The lowest number of leaves produced ( 25 leaves/plant) was recorded with the control $(0 \mathrm{t}$. ha- 1 of compost $+0 \%$ of FMR dose).

The ANOVA also showed a very highly significant difference $(\mathrm{P}<0.0001)$ in the number of tillers produced between the different treatments (Figure $4 \mathrm{~b}$ ). The highest number of tillers was obtained with treatments T5 (5 t. ha ${ }^{-1}$ of compost $+100 \%$ of FMR dose) $\left(14\right.$ tillers $\left./ \mathrm{m}^{2}\right)$ and T8 (7.5 t. ha ${ }^{-1}$ of compost $+100 \%$ of FMR dose $)\left(13\right.$ tillers $\left./ \mathrm{m}^{2}\right)$. The lowest number of tillers was recorded with the control $\left(0\right.$ t. ha ${ }^{-1}$ of compost $+0 \%$ of FMR dose $)\left(7\right.$ tillers $\left./ \mathrm{m}^{2}\right)$. 

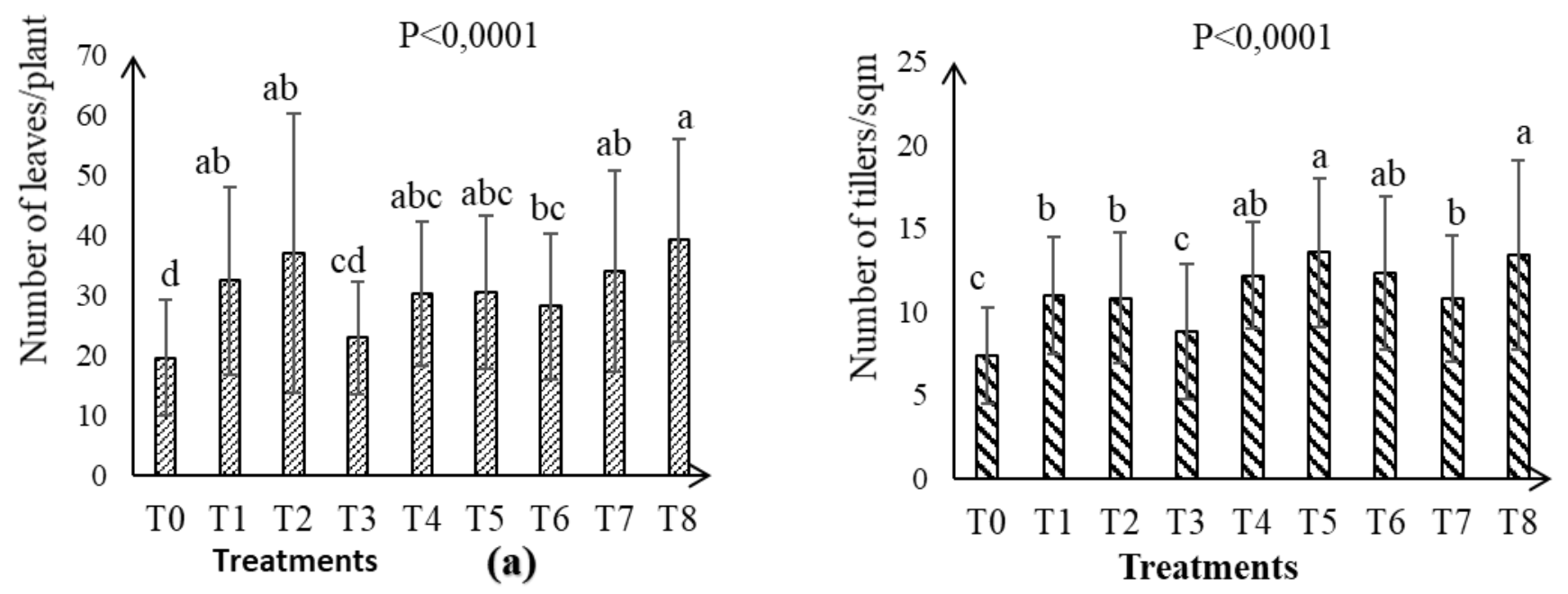

Figure 4: Effects of treatments on the number of leaves per plant (a) and the number of tillers per $\mathrm{m}^{2}(\mathrm{~b})$.

\subsection{Sanio millet plant height according to treatments and measurement dates}

The analysis of variance revealed no significant difference in plant height between treatments at 43rd, 72nd and 87th DAS (Table 1). However, with the exception of these dates, treatments significantly influenced plant height. Overall, treatment T8 $\left(7.5 \mathrm{t}^{- \text {ha }^{-1}}\right.$ of compost $+100 \%$ of FMR dose) had the highest mean plant height $(327.6 \pm 41 \mathrm{~cm})$ followed by treatment T4 $(5 \mathrm{t}$. ha1 of compost $+50 \%$ of FMR dose) with a mean height of $314.3 \pm 10 \mathrm{~cm}$ at the 117 th DAS. The control gave the lowest plant height with $227.5 \pm 14.4 \mathrm{~cm}$ at this date. 
International Journal of Agriculture, Environment and Bioresearch

Vol. 06, No. 06; 2021

ISSN: $2456-8643$

Table 1: Variation in plant height $(\mathrm{cm})$ according to treatments and measurement dates

\begin{tabular}{|c|c|c|c|c|c|c|}
\hline \multicolumn{7}{|c|}{ Measurement dates } \\
\hline Treatments & $43 \mathrm{JAS}$ & 57 JAS & 72 JAS & 87 JAS & $102 \mathrm{JAS}$ & $117 \mathrm{JAS}$ \\
\hline T0 & $53,3 \pm 20,8^{a}$ & $76 \pm 2^{c}$ & $94,5 \pm 2,7^{\mathrm{a}}$ & $155,5 \pm 17,2$ & $204 \pm 7,2^{b}$ & $227,5 \pm 14,4^{b}$ \\
\hline T1 & $41,2 \pm 20,6^{\mathrm{a}}$ & $\underset{\mathrm{bc}}{90,3 \pm 11,3}$ & $\underset{\mathrm{a}}{110,6} \pm 29,6$ & $\underset{\mathrm{a}}{182,5} \pm 65,2$ & $\underset{\mathrm{ab}}{247,1} \pm 47,2$ & $\underset{\mathrm{ab}}{274,4} \pm 50,6$ \\
\hline $\mathbf{T 2}$ & $34,3 \pm 14,6^{\mathrm{a}}$ & $85,1 \pm 6,8^{\text {bc }}$ & $\underset{\mathrm{a}}{103,6} \pm 10,1$ & $\underset{\mathrm{a}}{182,1} \pm 21,8$ & $237 \pm 43,7^{a b}$ & $257 \pm 43,8^{a b}$ \\
\hline T3 & $41,7 \pm 19^{a}$ & $97,5 \pm 5,9^{b}$ & ${ }_{\mathrm{a}}^{116,1} \pm 25,4$ & ${ }_{a}^{184,3} \pm 47,8$ & $\underset{\mathrm{ab}}{237,4} \pm 44,2$ & $\underset{\mathrm{ab}}{270,6} \pm 47,9$ \\
\hline T4 & $40,7 \pm 17,5^{\mathrm{a}}$ & $94,7 \pm 2,5^{b}$ & $121,5 \pm 8,3^{\mathrm{a}}$ & $\underset{\mathrm{a}}{208,2} \pm 18,5$ & $280 \pm 16,9^{a}$ & $314,3 \pm 10^{\mathrm{a}}$ \\
\hline T5 & $\begin{array}{l}36,5 \pm 18,8 \\
a\end{array}$ & $88,7 \pm 9,4^{\mathrm{bc}}$ & ${ }_{\mathrm{a}}^{11,3} \pm 24,7$ & $174,6 \pm 56,4$ & $\underset{\mathrm{ab}}{237,4} \pm 34,5$ & $280 \pm 44,7^{\mathrm{ab}}$ \\
\hline T6 & $39,5 \pm 17,4^{a}$ & $\underset{b c}{85,5} \pm 3,30$ & $\begin{array}{l}104,9 \pm 10,5 \\
\mathrm{a}\end{array}$ & $\underset{\mathrm{a}}{174,6 \pm 11,2}$ & $\underset{\mathrm{ab}}{242,5} \pm 8,7$ & $\underset{\mathrm{ab}}{289,6} \pm 18,3$ \\
\hline T7 & $41,4 \pm 17,9^{a}$ & $97,3 \pm 10,1^{b}$ & ${ }_{\mathrm{a}}^{126,5} \pm 17,2$ & $\underset{\mathrm{a}}{21,3} \pm 33,7$ & $275,7 \pm 32^{a b}$ & $\underset{\mathrm{ab}}{293,7} \pm 28,3$ \\
\hline T8 & $44 \pm 19,8^{\mathrm{a}}$ & $111,9 \pm 8,6^{\mathrm{a}}$ & $\begin{array}{l}132,8 \pm 30,5 \\
\mathrm{a}\end{array}$ & $214,5 \pm 51^{a}$ & $\begin{array}{l}286,6 \pm 25,2 \\
\mathrm{a}\end{array}$ & $327,6 \pm 41^{\text {a }}$ \\
\hline Average & 41,4 & 91,9 & 113,5 & 187,5 & 249,7 & 281,7 \\
\hline Probability & 0,948 & $<0,0001$ & 0,234 & 0,486 & $\mathbf{0 , 0 2 6}$ & $\mathbf{0 , 0 2 6}$ \\
\hline
\end{tabular}

3.4. Sanio millet Plants collar diameter according to treatments and measurement dates Except for the dates of 43rd DAS and 57th DAS, the analysis of variance showed a significant effect of treatments on the diameter at the collar (Table 2). Indeed, treatment T2 $\left(0 \mathrm{t}^{\mathrm{h}} \mathrm{ha}^{-1}\right.$ compost $+100 \%$ of FMR dose) recorded the highest collar diameters at 72nd DAS $(14.7 \pm 2.1$ $\mathrm{mm})$ and 117th DAS $(15.4 \pm 0.9 \mathrm{~mm})$. However, the highest collar diameters were obtained with treatment T8 (7.5 t. ha ${ }^{-1}$ compost $+100 \%$ of FMR dose) for the dates of 87th DAS (15.5 \pm 1.7 $\mathrm{mm})$ and $102 \mathrm{nd}$ DAS $(16.9 \pm 2.4 \mathrm{~mm})$. The smallest diameter was obtained with the control $(12.9 \pm 0.9 \mathrm{~mm})$.

Table 2: Variation in plant collar diameter $(\mathrm{mm})$ according to treatments

\begin{tabular}{|c|c|c|c|c|c|c|}
\hline \multicolumn{7}{|c|}{ Measurement dates } \\
\hline Treatments & $43 \mathrm{JAS}$ & 57 JAS & 72 JAS & 87 JAS & $102 \mathrm{JAS}$ & $117 \mathrm{JAS}$ \\
\hline T0 & $7,1 \pm 4,2^{a}$ & $10,1 \pm 1^{a}$ & $10,8 \pm 0,8^{b}$ & $11,6 \pm 0,9^{\mathrm{c}}$ & $11,1,3^{\mathrm{c}}$ & $12,9 \pm 0,9^{b}$ \\
\hline T1 & $7,8 \pm 2,6^{\mathrm{a}}$ & $12,2 \pm 1,7^{\mathrm{a}}$ & $11,7 \pm 0,4^{a b}$ & $12,6 \pm 0,7^{b c}$ & $13 \pm 2,5^{b c}$ & $12,9 \pm 1,7^{a b}$ \\
\hline $\mathbf{T} 2$ & $7,5 \pm 4,1^{\mathrm{a}}$ & $11,4 \pm 0,8^{a}$ & $14,7 \pm 2,1^{\mathrm{a}}$ & $13,8 \pm 0,8^{a b}$ & $14,3 \pm 0,2^{a b c}$ & $15,4 \pm 0,9^{\mathrm{a}}$ \\
\hline T3 & $8,8 \pm 2,9^{\mathrm{a}}$ & $10,8 \pm 0,4^{a}$ & $12,8 \pm 0,6^{a b}$ & $13,2 \pm 0,4^{b c}$ & $14,4 \pm 1,1^{a b c}$ & $13,7 \pm 1,4^{\mathrm{ab}}$ \\
\hline $\mathbf{T 4}$ & $9,6 \pm 3,2^{\mathrm{a}}$ & $11,2 \pm 1,9^{\mathrm{a}}$ & $13,4 \pm 1,3^{a b}$ & $14,5 \pm 0,3^{a b}$ & $13,8 \pm 0,4^{a b c}$ & $14,7 \pm 0,9^{\mathrm{a}}$ \\
\hline
\end{tabular}


ISSN: $2456-8643$

\begin{tabular}{|lllllll|} 
T5 & $7,6 \pm 2^{\mathrm{a}}$ & $12,5 \pm 0,8^{\mathrm{a}}$ & $13,4 \pm 1,2^{\mathrm{ab}}$ & $13,1 \pm 0,5^{\mathrm{bc}}$ & $12,7 \pm 0,8^{\mathrm{bc}}$ & $14,3 \pm 1,1^{\mathrm{a}}$ \\
T6 & $9,3 \pm 3,8^{\mathrm{a}}$ & $10,5 \pm 0,7^{\mathrm{a}}$ & $12,2 \pm 1,2^{\mathrm{ab}}$ & $12,3 \pm 0,7^{\mathrm{bc}}$ & $12,7 \pm 1,5^{\mathrm{bc}}$ & $12,5 \pm 1,1^{\mathrm{ab}}$ \\
T7 & $9,8 \pm 3,4^{\mathrm{a}}$ & $12,9 \pm 3,4^{\mathrm{a}}$ & $13,8 \pm 2,5^{\mathrm{ab}}$ & $14,2 \pm 1,8^{\mathrm{ab}}$ & $15,5 \pm 1,3^{\mathrm{ab}}$ & $14,3^{\mathrm{a}} \pm 1,8^{\mathrm{a}}$ \\
T8 & $10,9 \pm 22^{\mathrm{a}}$ & $13 \pm 1,8^{\mathrm{a}}$ & $12,9 \pm 1,2^{\mathrm{ab}}$ & $15,5 \pm 1,7^{\mathrm{a}}$ & $16,9 \pm 2,4^{\mathrm{a}}$ & $15,1^{\mathrm{a}} \pm 1,8^{\mathrm{a}}$ \\
\hline Average & $\mathbf{8 , 7}$ & $\mathbf{1 1 , 6}$ & $\mathbf{1 2 , 9}$ & $\mathbf{1 3 , 4}$ & $\mathbf{1 3 , 8}$ & $\mathbf{1 4 , 0}$ \\
\hline Probability & $\mathbf{0 , 7 6 2}$ & $\mathbf{0 , 1 6 8}$ & $\mathbf{0 , 0 2 8}$ & $\mathbf{0 , 0 0 0 3}$ & $\mathbf{0 , 0 0 1}$ & $\mathbf{0 , 0 0 5}$ \\
\hline
\end{tabular}

3.5. Number of leaves produced per sanio millet plant as a function of treatments according to measurement dates

Treatments had no significant effect on the number of leaves produced by the plants according to the measurement dates, except for the 87th and 117th days of the week (Table 3). However, in absolute value, treatments T2 ( 0 t. ha- 1 of compost $+100 \%$ of the FMR dose) and T8 (7.5 t. ha-1 of compost $+100 \%$ of the FMR dose) recorded the best results with respectively $49.81 \pm 36.52$ leaves/plant and $47.81 \pm 15.49$ leaves/plant at the 102nd DAS. At the last measurement date (117th DAS) the highest leaf productions were obtained with these same treatments with respectively $61.93 \pm 20.74$ leaves/plant and $60.06 \pm 13.03$ leaves/plant. The control gave the lowest number of leaves at this date with $24.87 \pm 11.65$ leaves/plant.

Table 3: variation in the number of leaves produced per millet plant according to the treatments

\begin{tabular}{|c|c|c|c|c|c|c|}
\hline \multicolumn{7}{|c|}{ Measurement dates } \\
\hline Treatments & $43 \mathrm{JAS}$ & 57 JAS & 72 JAS & 87 JAS & 102 JAS & 117JAS \\
\hline T0 & $11,93 \pm 5,71^{a}$ & $15,5 \pm 9,08^{a}$ & $\begin{array}{l}\text { a } \\
\text { a }\end{array}$ & $23 \pm 9,12^{\mathrm{a}}$ & $\underset{\mathrm{a}}{25,18 \pm 11,93}$ & $\begin{array}{l}24,87 \pm 11,65 \\
\mathrm{~b}\end{array}$ \\
\hline T1 & $17,56 \pm 3,24^{\mathrm{a}}$ & $\begin{array}{l}25,62 \\
10,09^{a}\end{array}$ & $\begin{array}{l}36,00 \\
11,72^{a}\end{array}$ & $\begin{array}{l}36,25 \\
16,66^{\mathrm{a}}\end{array}$ & $\underset{\mathrm{a}}{36,75 \pm 20,24}$ & $\begin{array}{l}42,00 \pm 20,34 \\
\mathrm{ab}\end{array}$ \\
\hline $\mathbf{T} 2$ & $\underset{\mathrm{a}}{20,12 \pm 11,49}$ & $\underset{\mathrm{a}}{20,31 \pm 9,47}$ & $\begin{array}{l}25,68 \pm 4,31 \\
\mathrm{a}\end{array}$ & $\begin{array}{l}44,06 \pm 8,61 \\
\text { a }\end{array}$ & $\begin{array}{l}49,81 \pm 36,52 \\
\text { a }\end{array}$ & $\begin{array}{l}61,93 \pm 20,74 \\
\text { a }\end{array}$ \\
\hline T3 & $14,68 \pm 7,34^{a}$ & $\underset{\mathrm{a}}{15,06 \pm 1,53}$ & $\begin{array}{l}24,68 \pm 8,73 \\
\text { a }\end{array}$ & $\begin{array}{l}23,12 \pm 7,31 \\
\text { a }\end{array}$ & $\begin{array}{l}26,50 \pm 11,22 \\
\mathrm{a}\end{array}$ & $\underset{\mathrm{ab}}{33,25 \pm 5,30}$ \\
\hline T4 & $17,62 \pm 8,04^{a}$ & $\underset{\mathrm{a}}{19,81 \pm 5,57}$ & $\begin{array}{l}32,43 \pm 6,20 \\
\text { a }\end{array}$ & $\begin{array}{l}37,00 \\
11,29^{\mathrm{a}}\end{array}$ & $38,00 \pm 8,16^{\mathrm{a}}$ & $\begin{array}{l}37,12 \pm 14,36 \\
\mathrm{ab}\end{array}$ \\
\hline T5 & $17 \pm 1,08^{a}$ & $\underset{\mathrm{a}}{15,81 \pm 4,54}$ & $\underset{a}{28,75} \pm 4,20$ & $\begin{array}{l}39,12 \\
11,84^{\mathrm{a}}\end{array}$ & $40,93 \pm 5,07^{\mathrm{a}}$ & $\begin{array}{l}41,00 \pm 10,66 \\
a b\end{array}$ \\
\hline T6 & $16,93 \pm 3,58^{a}$ & $\begin{array}{l}18,56 \pm 6,68 \\
\text { a }\end{array}$ & $\underset{\mathrm{a}}{21,43 \pm 6,81}$ & $\begin{array}{l}31,50 \pm 8,57 \\
\text { a }\end{array}$ & $\underset{\mathrm{a}}{37,81 \pm 12,70}$ & $\begin{array}{l}42,75 \pm 4,40 \\
\mathrm{ab}\end{array}$ \\
\hline T7 & $13,75 \pm 4,89^{a}$ & $\underset{\mathrm{a}}{26,37 \pm 8,22}$ & $\begin{array}{l}31,56 \\
21,75^{\text {a }}\end{array}$ & $\begin{array}{l}42,50 \\
15,07 \text { a }\end{array}$ & $\begin{array}{l}43,37 \pm 13,65 \\
\mathrm{a}\end{array}$ & $\begin{array}{l}46,75 \pm 9,91 \\
\mathrm{ab}\end{array}$ \\
\hline T8 & $23,31 \pm 6,62^{a}$ & $\underset{\mathrm{a}}{27,00 \pm 4,73}$ & $\begin{array}{l}29,81 \pm 6,62 \\
\text { a }\end{array}$ & $\begin{array}{l}46,56 \\
15,51^{a}\end{array}$ & $\begin{array}{l}47,81 \pm 15,49 \\
\mathrm{a}\end{array}$ & $\begin{array}{l}60,06 \pm 13,03 \\
\text { a }\end{array}$ \\
\hline Average & 16,9 & 20,4 & 27,5 & 35,9 & 38,4 & 43,3 \\
\hline Probability & $\mathbf{0 , 3 9 3}$ & 0,123 & 0,245 & $\mathbf{0 , 0 8 1}$ & 0,492 & $\mathbf{0 , 0 1 2}$ \\
\hline
\end{tabular}




\subsection{Millet tillers production according to treatments and measurement dates}

The analysis of variance indicated a significant effect of treatments on millet tillers production except at 43rd, 57th and 72nd days of age (Table 4). The treatments had a very high significant effect on the number of tillers produced at the 117th DAS. Indeed, the highest number of tillers was obtained with treatment T8 ( $7.5 \mathrm{t} \mathrm{ha}^{-1}$ of compost $+100 \%$ of FMR dose) with $20.37 \pm 3.70$ tillers $/ \mathrm{m}^{2}$ followed by treatment T5 (5 t. ha ${ }^{-1}$ of compost $+100 \%$ of FMR dose) with $18.52 \pm$ 3.02 tillers $/ \mathrm{m}^{2}$ at 117 th DAS. The lowest number of tillers produced was recorded at this date with the control $\left(8.33 \pm 3.55\right.$ tillers $\left./ \mathrm{m}^{2}\right)$.

Table 4: variation in the number of tillers produced per $\mathbf{m}^{2}$ by sanio millet plants according to the treatments

\begin{tabular}{|c|c|c|c|c|c|c|}
\hline \multicolumn{7}{|c|}{ Measurement dates } \\
\hline Treatments & $43 \mathrm{JAS}$ & 57 JAS & 72 JAS & 87 JAS & $102 \mathrm{JAS}$ & $117 \mathrm{JAS}$ \\
\hline T0 & $5,56 \pm 2,14^{\mathrm{a}}$ & $6,48 \pm 3,55^{\mathrm{a}}$ & $7,41 \pm 3,02^{a}$ & $8,33 \pm 1,85^{\mathrm{c}}$ & $8,33 \pm 3,55^{a}$ & $8,33 \pm 3,55^{d}$ \\
\hline T1 & $9,26 \pm 4,78^{a}$ & $9,26 \pm 4,78^{a}$ & ${ }_{\mathrm{a}}^{11,11} \pm 3,02$ & $\underset{\mathrm{abc}}{12,04} \pm 1,85$ & $12,04 \pm 1,85$ & $12,04 \pm 4,66^{\mathrm{bcd}}$ \\
\hline T2 & $7,41 \pm 0,00^{\mathrm{a}}$ & $8,33 \pm 3,55^{\mathrm{a}}$ & $8,33 \pm 1,85^{\mathrm{a}}$ & $\underset{\mathrm{abc}}{10,19} \pm 1,85$ & $\begin{array}{l}141,81 \\
3,02^{a}\end{array}$ & $15,74 \pm 1,85^{\mathrm{abc}}$ \\
\hline T3 & $6,48 \pm 3,55^{a}$ & $7,41 \pm 4,28^{a}$ & $7,41 \pm 3,02^{a}$ & $9,26 \pm 4,78^{b c}$ & ${ }_{\mathrm{a}}^{11,11 \pm 5,24}$ & $11,11 \pm 3,02^{\mathrm{cd}}$ \\
\hline T4 & $7,41 \pm 0,00^{\mathrm{a}}$ & $\underset{\mathrm{a}}{11,11} \pm 0,00$ & $\underset{\mathrm{a}}{11,11 \pm 3,02}$ & $\underset{\mathrm{abc}}{12,96} \pm 2,14$ & $\underset{\mathrm{a}}{14,81 \pm 0,00}$ & $15,74 \pm 1,85^{a b c}$ \\
\hline T5 & $6,48 \pm 1,85^{\mathrm{a}}$ & $\begin{array}{l}11,11 \pm 0,00 \\
\mathrm{a}\end{array}$ & $\frac{12,96 \pm 2,14}{a}$ & $15,74 \pm 1,85^{\mathrm{a}}$ & $\underset{\mathrm{a}}{16,67 \pm 2,14}$ & $18,52 \pm 3,02^{a b}$ \\
\hline T6 & $6,48 \pm 1,85^{a}$ & $\underset{\mathrm{a}}{10,19} \pm 3,55$ & $\underset{\mathrm{a}}{10,19 \pm 1,85}$ & $\underset{\mathrm{ab}}{14,81 \pm 3,02}$ & $\underset{\mathrm{a}}{15,74 \pm 4,66}$ & $16,67 \pm 2,14 \mathrm{abc}$ \\
\hline T7 & $5,56 \pm 2,14^{\mathrm{a}}$ & $9,26 \pm 2,14^{\mathrm{a}}$ & ${ }_{\mathrm{a}}^{11,11} \pm 3,02$ & ${ }_{\mathrm{abc}}^{11,11} \pm 3,02$ & $\underset{a}{12,04} \pm 1,85$ & $15,74 \pm 1,85^{a b c}$ \\
\hline T8 & $7,41 \pm 0,00^{\mathrm{a}}$ & $9,26 \pm 2,14^{\mathrm{a}}$ & $\begin{array}{l}11,11 \pm 3,02 \\
\text { a }\end{array}$ & $\begin{array}{l}15,74 \pm 3,55 \\
\text { ab }\end{array}$ & ${ }_{\mathrm{a}}^{16,67 \pm 6,42}$ & $20,37 \pm 3,70^{\mathrm{a}}$ \\
\hline Aver & 6,89 & 9,16 & 10,08 & 12,24 & 13,58 & 14,92 \\
\hline robability & 0,518 & 0,456 & 0,081 & 0,004 & 0,044 & 0,0001 \\
\hline
\end{tabular}

3.7. Biomass production in ears and straw of Sanio millet

Analysis of variance revealed a significant difference $(\mathrm{P}=0.035)$ in spike biomass as a function of treatments (Figure 5a). The highest spike biomass production $\left(1.219 \mathrm{t}^{\mathrm{t}} \mathrm{ha}^{-1}\right)$ was obtained with treatment T8 $\left(7.5 \mathrm{t}^{\text {. ha }} \mathrm{a}^{-1}\right.$ compost $+100 \%$ FMR dose). The lowest ear biomass $\left(0.439 \mathrm{t}^{\mathrm{t}} \mathrm{ha}^{-1}\right)$ was obtained with the control ( 0 t. ha ${ }^{-1}$ compost $+0 \%$ FMR dose) followed by treatment T3 (5 t. ha ${ }^{-1}$ compost $+0 \%$ FMR dose) with 0.553 t. ha ${ }^{-1}$.

Analysis of variance showed a highly significant difference $(\mathrm{P}=0.004)$ in straw production between treatments (Figure 5b). As with the spike biomass, treatment T8 $\left(7.5 \mathrm{t}^{-\mathrm{ha}^{-1}}\right.$ of compost $+100 \%$ of FMR dose) performed best with a biomass production of $7.288 \mathrm{t}^{\text {. ha }}{ }^{-1}$. The T0 
control $\left(0\right.$ t. ha ${ }^{-1}$ compost $+0 \%$ FMR dose $)$ and T3 treatment $\left(5\right.$ t. ha ${ }^{-1}$ compost $+0 \%$ FMR dose) had the lowest straw biomass production with $1.867 \mathrm{t} . ~ h a^{-1}$ and $2.982 \mathrm{t}^{\mathrm{t}} \mathrm{ha}^{-1}$ respectively (Figure $5 b)$.
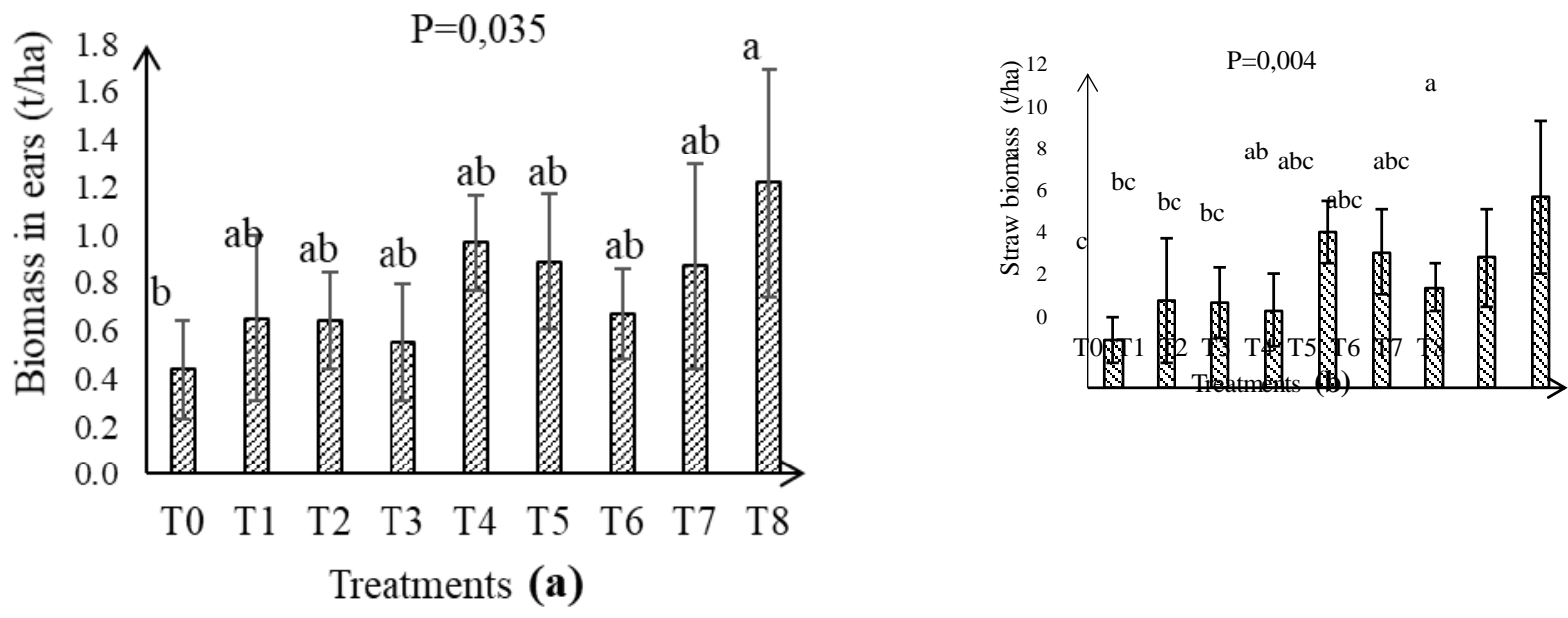

Figure 5: Effects of treatments on straw biomass (a) and cob biomass (b).

\subsection{Sanio millet ear production}

The ANOVA indicated that there was no significant difference in the number of ears produced per ha between treatments (Figure 6). However, in absolute terms, treatments T8 (7.5 t. ha ${ }^{-1}$ of compost $+100 \%$ of FMR dose) with 52,187 ears. ha-1 and T7 (7.5 t. ha ${ }^{-1}$ of compost $+50 \%$ of FMR dose) with 48,281 ears. ha ${ }^{-1}$ gave the best results (Figure 6) The lowest number of ears produced was recorded with treatment T3 (5 t. ha ${ }^{-1}$ of compost $+0 \%$ of FMR dose) with 36,563 ears. ha ${ }^{-1}$.

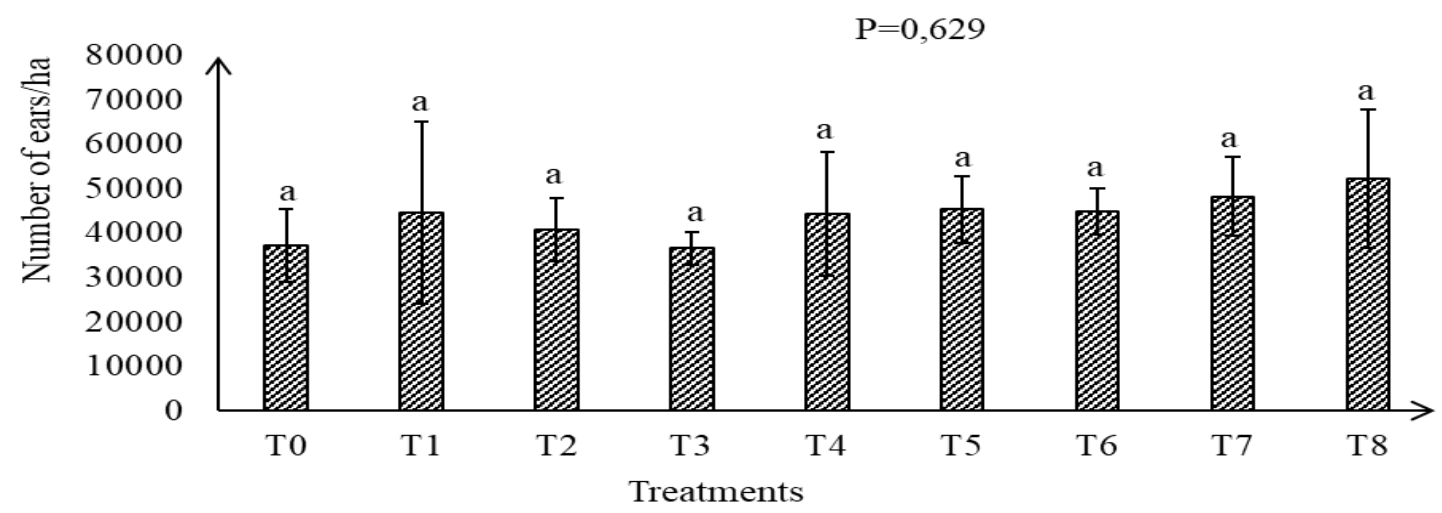

Figure 6: Effect of treatments on the number of sanio millet ears produced per hectare 


\subsection{0-grain weight of Sanio millet.}

Analysis of variance showed that 1000 -grain weight was significantly influenced $(\mathrm{P}=0.011)$ by treatments (Figure 7). Treatment T6 (7.5 t. ha ${ }^{-1}$ of compost $+0 \%$ of FMR dose) gave the best result with an average weight of $6.220 \mathrm{~g}$. The lowest value was obtained with treatments T2 $(0 \mathrm{t}$. ha- 1 compost $+100 \%$ of FMR dose $)$ and $\mathrm{T} 1\left(0 \mathrm{t}\right.$. ha $\mathrm{h}^{-1}$ compost $+50 \%$ of FMR dose $)$ with $5.177 \mathrm{~g}$.

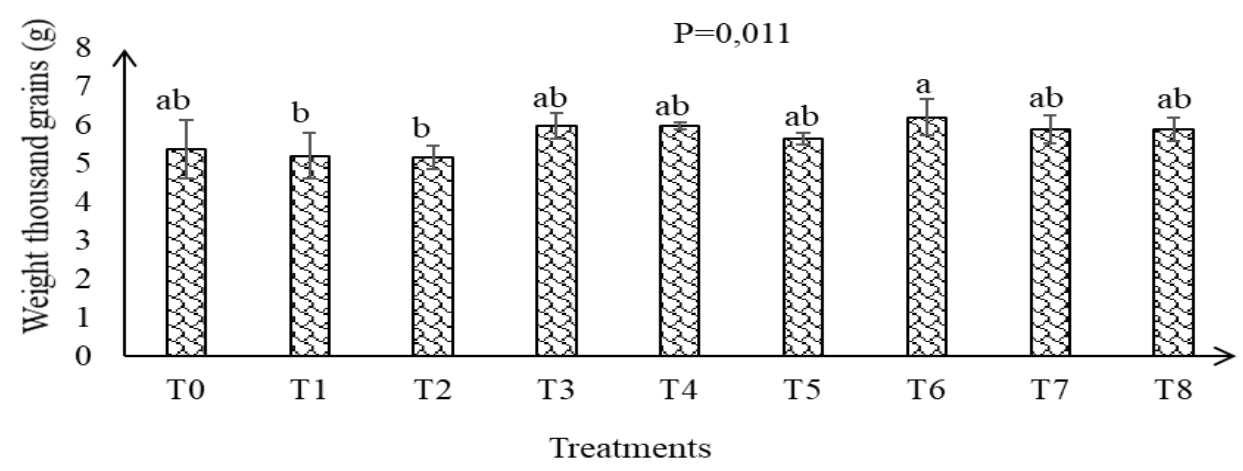

Figure 7: Effect of treatments on thousand grain weight of Sanio millet.

\subsection{Grain yield of Sanio millet.}

As with the number of ears/ha, the analysis of variance showed that treatments had no effect $(\mathrm{P}=$ 0.131) on grain yield of millet (Figure 8). However, in absolute terms, the highest grain yield was recorded with treatment T8 $\left(7.5 \mathrm{t} . \mathrm{ha}^{-1}\right.$ of compost $+100 \%$ of the FMR dose) with $0.7781 \mathrm{t}$. $\mathrm{ha}^{-1}$. The lowest yield was obtained with the T0 control ( $0 \mathrm{t}$. ha-1 of compost $+0 \%$ of FMR dose) with 0.2602 t. ha ${ }^{-1}$.

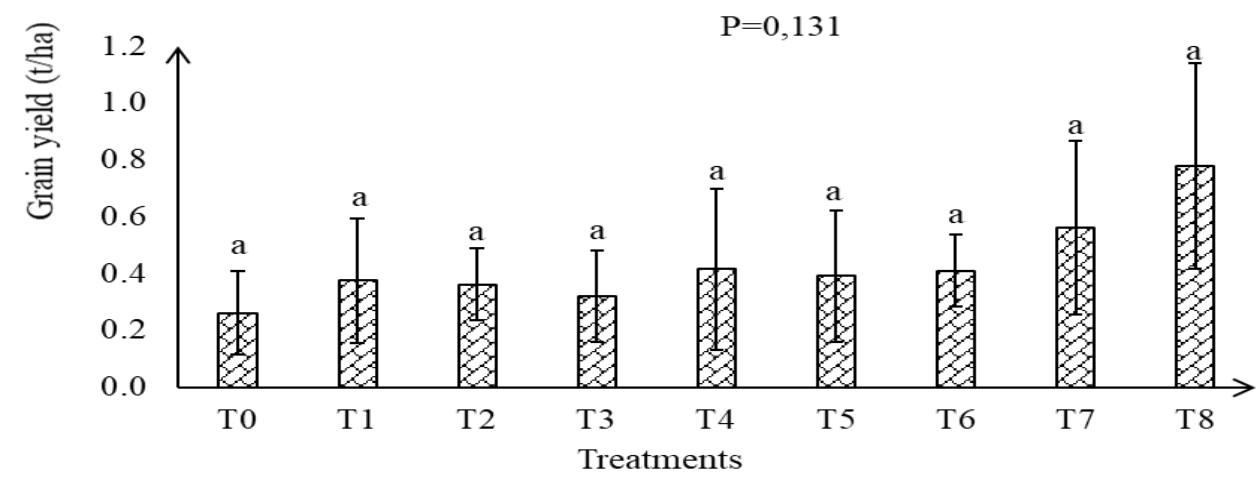

Figure 8: Effect of treatments on grain yield of millet.

\subsection{Correlation between the treatments and the parameters studied}

Principal component analysis (PCA) was performed on the basis of the growth and production parameters of the Sanio millet (Pennisetum glaucum) plants and the treatments tested. The F1 and F2 axes absorb $86.63 \%$ of the variability studied, which is sufficient for a good graphic 
representation of the information contained in the matrix. Variables such as spike biomass (14.378\%), straw biomass (14.31\%), plant height (13.08\%), grain yield (12.84\%), number of spikes/ha (12.45\%), crown diameter (11.68\%) and number of tillers (11.47\%) contribute $89.84 \%$ to the formation of the F1 axis while the PMG and NF variables contribute $55.91 \%$ to the formation of the $\mathrm{F} 2$ axis.

The analysis of figure 9 allows us to discriminate four groups of treatments:

- Group A consisting of treatments T4 (5 t. ha- 1 of compost + 50\% of the FMR dose), T5 (5 t. $\mathrm{ha}^{-1}$ of compost $+100 \%$ of the FMR dose), T7 (7.5 t. ha ${ }^{-1}$ of compost $+50 \%$ of the FMR dose) and T8 (7.5 t. ha ${ }^{-1}$ of compost $+100 \%$ of the FMR dose) which strongly influence height (304.1 $\mathrm{cm})$, crown diameter $(14.38 \mathrm{~mm})$, tillers production $\left(18\right.$ tillers $\left./ \mathrm{m}^{2}\right)$, straw biomass $(5.84 \mathrm{t}$. ha-1), spike biomass $\left(0.99\right.$ t. ha $\left.{ }^{-1}\right)$, number of spikes/ha (47,539 spikes. ha $\left.{ }^{-1}\right)$ and grain yield $(0.537 \mathrm{t}$. $\left.\mathrm{ha}^{-1}\right)$;

- Group B, consisting of treatments T3 (5 t. ha ${ }^{-1}$ of compost $+0 \%$ of FMR dose) and T6 (7.5t. ha ${ }^{1}$ of compost $+0 \%$ of FMR dose), which positively influenced the weight of thousand grains $(5.86 \mathrm{~g})$;

- Group C, consisting of treatments T1 $\left(0\right.$ t. ha ${ }^{-1}$ compost $+50 \%$ of FMR dose $)$ and T2 (0 t. ha ${ }^{-1}$ compost $+100 \%$ of FMR dose), which positively influenced leaf production (52 leaves/plant)

- Group D, the absolute control, characterized by low values of the following parameters: height, crown diameter, number of tillers $/ \mathrm{m}^{2}$, straw biomass, spike biomass, number of spikes/ha and grain yield.

Of all the growth parameters, the number of leaves produced is the least correlated with production parameters. On the other hand, the diameter at the collar, the height and the number of tillers are strongly correlated with the production parameters except for the weight of thousand grains. 


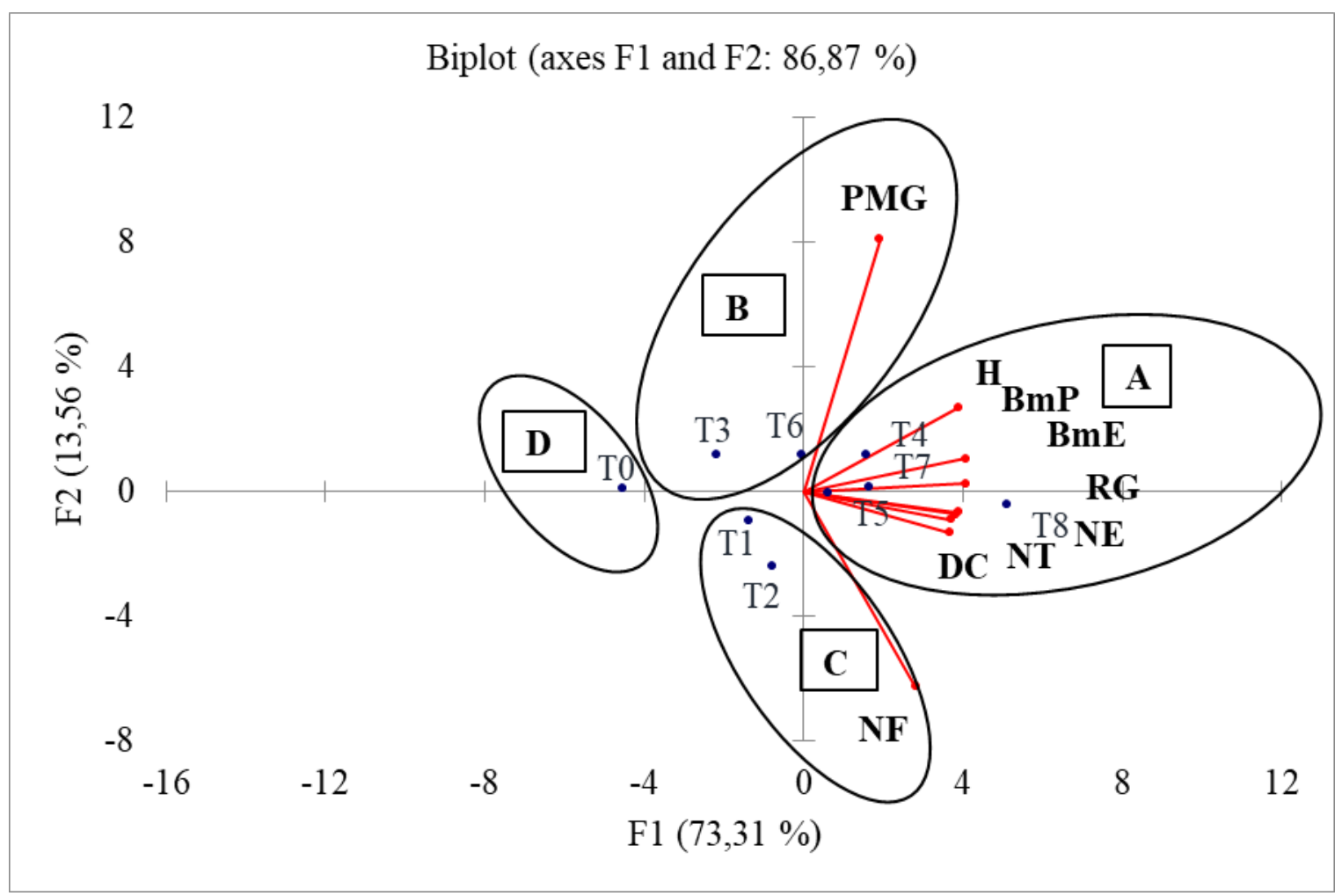

Figure 9: Typology of treatments applied to Sanio millet

\section{DISCUSSION}

This work consisted in determining the best dose of organo-mineral fertilization for sustainable production of Sanio millet in Lower Casamance.

Treatments in the presence of mineral fertilization were more effective on the number of leaves produced/plant. This can be explained by the fact that mineral fertilizer is made up of fertilizing elements that are directly assimilated by the crop [12]. Moreover, nitrogen favors the growth of the green parts of the plant (stem and leaves), their precocity and their development. These results corroborate those obtained by [13] and [14] according to which nitrogen nutrition is important for vegetative growth of millet.

The tallest plants $(189.26 \mathrm{~cm})$ are noted with the T8 treatment combining compost and FMR (7.5 t. ha ${ }^{-1}$ compost $+100 \%$ of FMR dose). These results are in line with those of [15] who showed a positive effect of organo-mineral fertilization on millet plant height and those of [16] (2017) and [17] who showed a positive effect of this fertilization on sorghum and fonio respectively. Similarly this organo-mineral fertilization gave the largest diameter at the collar $(14.08 \mathrm{~mm})$, confirming the results of [18] who noted a significant influence of organic matter inputs combined with mineral fertilizers on the diameter of cassava stems.

These same results are observed with the number of tillers. Indeed, the T5 treatment with $5 \mathrm{t}_{\text {. ha }}{ }^{-1}$ of compost $+100 \%$ FMR performed better $\left(14\right.$ tillers $\left./ \mathrm{m}^{2}\right)$. This can be explained by the use of the maximum dose of FMR, thus confirming the work of [13] who showed an increase in the 
Vol. 06, No. 06; 2021

ISSN: $2456-8643$

number of tillers of millet following mineral fertilization. Tiller production is an important criterion in biomass production. Compared to the control, the treatments had a significant effect on tillers production. In addition, compost is characterized by a low rate of nutrient release while mineral fertilizers are characterized by a high rate of nutrient release in the short term [19].

The interaction between the amendment and mineral fertilization has a positive effect on both growth and production parameters with 7.29 t. ha- 1 for straw biomass, $1.22 \mathrm{t}$. ha- 1 for ear biomass, $0.78 \mathrm{t}$. ha-1 for grain yield and 52,188 ears/ha for number of ears produced for Sanio millet. These results are in agreement with those found by [20] who showed a significant effect of organo-mineral fertilization on growth and production parameters of Sanio millet.

The use of organo-mineral fertilization significantly increases the yield of Sanio millet. These results corroborate those of [21]; 2014 who showed as a function of the doses of organic manure and mineral fertilizer that the increase in grain yield varied from 5 to $36 \%, 11$ to $25 \%$ and 49 to $87 \%$ for millet. Similar results were found by [22] and [23] who showed that the joint application of mineral and organic manure increased maize and rice production.

Principal component analysis (PCA) revealed a positive relationship between growth $(\mathrm{H}, \mathrm{DC}$, $\mathrm{NT})$ and production $(\mathrm{BmE}, \mathrm{BmP}, \mathrm{NE}, \mathrm{RG})$ parameters and treatments. Moreover, compost alone corresponding to treatments T3 $\left(5 \mathrm{t} . \mathrm{ha}^{-1}\right.$ of compost $+0 \%$ of FMR dose) and T6 (7.5 t. ha ${ }^{-1}$ of compost $+0 \%$ of FMR dose) only positively influenced thousand kernel weight (MGW) while mineral fertilization corresponding to treatments $\mathrm{T} 1(0 \mathrm{t}$. ha- 1 of compost $+50 \%$ of the FMR dose) and T2 (0 t. ha ${ }^{-1}$ of compost $+100 \%$ of the FMR dose) had a positive effect only on the number of leaves produced (NF).

The application of compost alone at the rate of $7.5 \mathrm{t}$. ha ${ }^{-1}$ performed better than mineral fertilization alone on the weight of 1000 grains: varying from $5.177 \mathrm{~g}$ to $6.220 \mathrm{~g}$. This result could be explained by the effect of the optimization of compost by burial which allows to renew and increase the level of mobilizable nitrogen in the soil and to concentrate it in space for an efficient use, which is important for the filling of the grains. In fact, the compost allows to reconstitute the properties of the soil and revitalizes the biological activities. Thus, the appearance of earthworm castings and the activities of soil bacteria contribute visibly to the cohesion of the soil. This result corroborates the work of [24] who showed that the application of household waste on maize gives a better weight of 1000 grains compared to the treatment of maize with mineral manure.

For all growth parameters, except for the number of leaves, the results showed a significant effect of organo-mineral fertilization at the end of the experiment (117th DAS). This increase can be explained by the fact that the application of organic amendments and mineral fertilizers makes growth elements such as phosphorus more available as indicated by [16]. In addition nitrogen in compost is provided in organic form; which requires transformation of organic nitrogen into mineral nitrogen for proper plant uptake [25].

\section{CONCLUSION}

This study revealed the effect of organo-mineral fertilization on the agronomic performance of sanio millet in Lower Casamance.

Indeed, the study revealed a highly significant effect of the treatments on the growth and production parameters of sanio millet. The best results for height, crown diameter and number of 
Vol. 06, No. 06; 2021

ISSN: $2456-8643$

leaves produced were obtained with treatment T8 $\left(7.5 \mathrm{t}^{-h^{-1}}\right.$ of compost $+100 \%$ of the FMR dose).

In terms of agronomic performance, the experiment showed that, in absolute terms, compost combined with mineral fertilization favored good production of Sanio millet.

The best grain yield $\left(0.7781 \mathrm{t}\right.$. ha $\left.{ }^{-1}\right)$ was obtained with the combination of compost at $7.5 \mathrm{t} \mathrm{ha}^{-1}$ and mineral fertilization at $100 \%$ FMR. Compost alone significantly improved 1000-grain weight. Overall, the treatments had no significant effect on grain yield.

Based on the trends in growth and plant biomass parameters, regular organo-mineral fertilization at T8 (7.5 t. ha ${ }^{-1}$ compost $+100 \%$ FMR) or compost alone at 7.5 t. ha ${ }^{-1}$ would be recommended to increase Sanio millet production.

It would be appropriate to continue the studies by replicating these trials in other agro-ecological zones in the south and southeast of Senegal in order to test these tests in a real environment for better soil management and millet production for the benefit of producers.

\section{ACKNOWLEDGEMENTS}

We would like to thank all the research staff and technicians of CRA/Djibélor for their active participation in the field activities. But also to all those who have contributed to the realization of this study.

\section{REFERENCES}

[1] Anonyme 2016a. Senegal: FAO confirms record cereal production of 2.27 tons in 2015. https//actuprime.com/Senegal-la Fao confirme -une -production, accessed April 2021.

[2] Ndiaye A. 2018. Effect of organo-mineral fertilization on growth and yield of Sanio millet (Pennisetum glaucum L. R. Br) in Upper Casamance (Senegal). Master's thesis in Agroforestry. Université Assane Seck de Ziguinchor (UASZ). 40 p.

[3] Batanio A., Christianson B.C., Baethgen Z.E., and Mokwunyne A.U. 1992. Afarm-lvel evaluation of nitrogen and phosphorus fertiliser use and planting density for pearl millet production in Niger. Fert. Res. 31: 175-184 p.

[4] Buerkert A., Batanio A., and Pierpho H.P. 2001. Efficient phosphorus application strategies for increased crop production in Sub-Saharan West Africa. Field Crop Res. 72: 1-15 p.

[5] Siene L.A.C., Muller B., Aké S., 2010. Study of the development and distribution of biomass in two millet varieties of different cycle length under three seeding densities. J. Appl. Biosci. 35: 2260-2278.

[6] Anonyme 2015. Economic and social situation of Senegal in 2012. ANSD. 09 p.

[7] Anonyme 2016b. Performance report. Ministry of Agriculture and Rural Equipment, Direction de l'Analyse de la Prévision et des Statistiques Agricoles (DAPSA),52 p.

[8] Ndiaye A. and Sawane O. 2015. Study of local cultivation practices of Sanio millet (Pennisetum glaucum L. R. Br) in farmers' plots in Upper Casamance (Senegal). Dissertation for a Bachelor's degree in Agroforestry, Assane Seck University of Ziguinchor (UASZ). 37p.

[9] Diouf F. K. and Manga W. 2019. Participatory evaluation of new rice varieties (isriz) in lowland rice cultivation at the CRA of Djibelor (Basse Casamance), Bachelor's thesis, Department of Agroforestry, Assane SECK University of Ziguinchor 38p.

[10] Sagna P., 2005. Dynamics of the climate and its recent evolution in the western part of West Africa. Thesis of doctorate of state letter UCAD. Tome 1 and 2, $742 \mathrm{p}$. 
[11] Diouf O. 2001. La culture du mil (Pennisetum glaucum (L.) R. Br.) en zone semi-aride : bases agrophysiologiques justificatives d'une fertilisation azotée. Dissertation of tenure ISRA. $75 \mathrm{p}$.

[12] Lacharme M. 2001. La fertilisation minérale du riz. Fascicule 6, Ministère du Développement Rural et de l'Environnement Direction de la Recherche Formation Vulgarisation, Coopération Française. 19 p.

[13] Eldin 1990. Growth and development of millet (Pennisetum typhoïdes) under two conditions of mineral manure, ISTOM. $53 \mathrm{p}$.

[14] Chaïbou Z. 2013. Effect of phospho-compost on millet (Pennisetum glaucum (L.) R.Br.) production: case of the urban commune of Niamey. Master II thesis at the Polytechnic University of Bobo-Dioulasso (UPB), Option: Soil Science, Specialty: Integrated Management of Soil Fertility, 56 p.

[15] Cissé L. 1988. Influence of organic matter inputs on the cultivation of millet and groundnut on a sandy soil in northern Senegal. II. Plant development and mineral mobilization. EDP Sciences, 8 (5), pp.411-417.

[16] Somda B. B., Ouattara B., Serme I., Pouya M. B., Lompo F., Taonda S. J. B., and Sedogo P. M. 2017. Determination of optimal doses of organo-mineral manures in microdose in the Sudano-Sahelian zone of Burkina Faso. International Journal of Biological and Chemical Sciences, 11 (2): 670-683, 15 p.

[17] Gueye M. 2016. Improvement of sowing, fertilization and harvesting techniques of white fonio (Digitaria exilis Stapf; Poaceae) in Eastern Senegal and Casamance (Senegal). Doctoral thesis, Faculty of Science and Technology, Cheikh Anta Diop University of Dakar, 137 p.

[18] Bilong E.G., Ajebesone F.N., Abossolo-Angue M., Birang À.M., Ndaka Bonguen S.M. and Bilong P. 2017. Effects of Tithonia diversifolia green biomass and mineral fertilizers on growth, development and yield of cassava (Manihot esculenta Crantz) in the forest zone of Cameroon. Int. J. Biol. Chem. Sci. 11(4): 1716-1726, 2017, $11 \mathrm{p}$

[19] Claassen V. P., and Carey, J. L. 2007. Comparison of slow-release nitrogen yield from organic soil amendments and chemical fertilizers and implications for regeneration of disturbed sites. Land Degradation and Development, 132, 119-132 p.

[20] Bamba B., 2020. Analysis of cultivation practices and sowing and fertilization techniques of Sanio millet (Pennisetum glaucum) (L.) R. Br] in Eastern Senegal and Casamance, Senegal. D. thesis, University of Assane Seck, Ziguinchor. 121 p.

[21] Zeinabou H., Mahamane S., Bismarck N. H., Bado B. V., Lompo F., and Bationo A., 2014. Effect of combined organo-mineral manures and cowpea-millet rotation on nitrogen nutrition and millet yields in the sahel. International Journal of Biological and Chemical Sciences, 8 (4), 1620-1632 p.

[22] Akanza P. and Yoro G. 2003. Synergistic effects of mineral fertilizers and poultry manure in improving the fertility of a ferralitic soil in western Côte d'Ivoire. African Agronomy 15 (3), 135-144 p.

[23] Akanza K.P., Sanogo S., Kouakou C.K., N'Da H.A., Yao-Kouamé A. 2014. Effects of fertilization on soil fertility and yields: implications for soil deficiency diagnosis. Rev. Ivoir. Sci. Technol, 24: 299-315. DOI: http//www.revist.ci 
[24] Ouattara L.A. 2014. Effect of rotations and manures based on Burkina Phosphate on the growth and yield of strict rainfed rice in the Sudanian zone of Burkina Faso. Master thesis, Polytechnic University of Bobo-Dioulasso. 59p.

[25] Cobo J.G., Barrios E., Kaas D.C.L and Thomas R.J. 2002. Nitrogen mineralization and crop uptake from surface-applied leaves of green manure species on a tropical volcanic-ash soil. Biology and fertility of soils, 36: 87- $92 \mathrm{p}$. 